\section{Iranian Journal of Educational Sociology}

Iranian journal of educational Sociology

(Interdisciplinary Journal of Education)

Available online at: http://www.iase-idje.ir/ Volume 4, Number 2, June 2021

\title{
Strategic Planning and Sociology in Improving the Quality of Life and Sustainable Development of Cities in Arid Regions Climates with Emphasis on MICE Tourism using Meta-SWOT and SOAR Techniques
}

\author{
Amin Pirmohammadzadeh ${ }^{1}$, Saeid Kamyabi ${ }^{* 2}$, Mohammad Reza Zandmoghadam ${ }^{3}$
}

1. PhD Student, Department of Geography and Urban Planning, Semnan Branch, Islamic Azad University, Semnan, Iran .

2. Associate Professor, Department of Geography, Semnan Branch, Islamic Azad University, Semnan, Iran.

3. Assistant Professor, Department of Geography, Semnan Branch, Islamic Azad University, Semnan, Iran.

\section{Article history:}

Received date: 2021/05/30

Review date: $2021 / 06 / 12$

Accepted date: 2021/06/17

\section{Keywords:}

Tourism, MICE Tourism, Meta SWOT, SOAR

\begin{abstract}
Purpose: This study was carried out with the aim of strategic tourism planning in Semnan with emphasis on MICE tourism using Meta SWOT and SOAR techniques.

Methodology: The descriptive-analytical method is used in order to conduct this research. The statistical population of the study is divided into three parts. The first part were local residents of Semnan, the second part includes tourists who have considered Semnan as a tourist destination from 2019 to 2020, and third part includes academic elites, managers, staff of tourism part working in different management levels of province. Three-hundred seventy people (three parts) were determined as the statistical sample size using Cochran formula. The method of data collection and analysis of required information is documentary and survey. Meta SWOT and SOAR analytical techniques have been used to formulate the development strategy and explain the goals, resources, capabilities and macro-environmental factors.

Findings: According to the obtained results, the most important factors in line with strategic tourism planning in Semnan are government policies, non-responsiveness of infrastructure, increased natural dangers and inflation and economic recession at the macro level.

Conclusion: Meta SWOT model is implemented in a program consisting of title window and seven interconnected windows. This tool enables unlimited reviews of inputs, because decision makers change their assessment during a planning activity.
\end{abstract}

Please cite this article as: Pir Mohammadzadeh A, Kamyabi S, Zandmoghadam M R. (2021), Strategic Planning and Sociology in Improving the Quality of Life and Sustainable Development of Cities in Arid Regions Climates with Emphasis on MICE Tourism using Meta-SWOT and SOAR Techniques, Iranian Journal of Educational Sociology, 4(2): 224-233.

\footnotetext{
* Corresponding Author: s.kamyabi@semnaniau.ac.ir
} 


\section{Introduction}

Since 1991, most of the research in the field of strategic planning for tourism has been done using the SWOT model. Regarding that most scientific methods and techniques are not always fixed and each paradigms, scientific methods and techniques are critiqued and discarded by new paradigms and methods, the SWOT model has long been criticized following its critiques about subjective and unsystematic conclusion, and planners are looking for a proper alternative to it in strategic planning. One of the methods used since 2012 is Meta SWOT strategic planning. Meta SWOT is an inward-looking strategic planning method that helps us to win in competing with competitors in the future by identifying and evaluating our competition scene with others and identifying the resources and capabilities of our internal environment and change our economic borders or common markets with competitors in favor of our collection (group); therefore, since third world countries have one-dimensional economies, by investing in the tourism industry and using efficient strategic planning methods, they can create a new source of income for themselves to boost their economies. Iran is no exception to this rule and can achieve its worthy position in the tourism industry with correct planning (Shokohi et al, 2018)

We are currently faced with two approaches: external to internal strategic planning and internal to external strategic planning. This type of classification depends on the factor of whether or not to use resources and capabilities, as well as micro and macro environmental factors in the beginning. In other words, the doctrine of strategic planning science agreed that top and popular organizations and companies have unique capabilities, which has caused them to have a position in the markets. Using creativity, these companies have developed an internal to external approach, based on this and relying on internal capabilities, they have distinguished themselves from others, in other words, they have created markets and shaped a competitive environment. Resource-based perspective insight is based on this assumption that firms are a collection of heterogeneous resources and capabilities, which these resources and capabilities are not transferable from firm to firm. This perspective also assumes that the resources and capabilities of each organization and group are their first advantage and distinguishing factor and brings them a kind of lasting and long-term superiority. Resources and abilities are assets, positive attributes, knowledge and any kind of comparative advantage that is available to a group and is effective in improving their future conditions. "Barney" added in 1991 that if a firm's resources and capabilities are valuable, scarcity, inimitable, irreplaceability and common in VRIO positions, they could create a continuous competitive advantage for the firm. What this article seeks to answer is that which strategic planning can help the development of MICE tourism in Semnan with the help of two Meta software SWOT and SOAR?

Several researches have been carried out on strategic planning for MICE tourism development. The results of research conducted by Zandmoghaddam \& Pir Mohammadzadeh (2018) showed that events are not only one of the most important sectors of tourism and their importance is increasing. There are a number of different kind of events in the world and their number is increasing every year. In this competitive positions, success in events depends on strategic planning and its proper implementation. Nasirian (2017) in his research has concluded that holding the cultural and sports festival of nomads of East Azerbaijan province in the city of Kalibar has affected all tourism development dimensions in this province. Bazrafshan (2017) in a study stated that holding business events plays an effective role in the economy, employment and being seasonal control of the destination community, improving trade relations, attracting visitors from other regions (domestic and foreign), attracting media attention and flowing direct capitals into a tourist destination, as well as improving infrastructure and meeting the needs of the host community along with the growth and development of the destination. Shiran (2013) in his study has stated that holding and managing meetings and conferences can lead to attract tourists to Isfahan and also Isfahan has the necessary structures to attract MICE tourism; and the facilities and structures like travel facilities in Isfahan such as hotels, agencies, transportation services, Internet services, etc., historical and cultural monuments, the use of appropriate advertising, distance from different places and how to access Isfahan, quality of Isfahan's climate and natural 
landscapes, the culture of the local people and the way they behave with tourists are effective in attracting more tourists to Isfahan and participating in meetings and conferences. In addition, there are challenges and obstacles such as the cost of attending meetings and conferences, exchange rate changes and political and legal security on the way of business tourism development in Isfahan. Bazrafshan (2017) in a study entitled "MICE tourism domain as an emerging hospitality industry" concluded that MICE tourism helps motivate employees to improve company productivity and gain popularity in the world of companies. Stavros (2018) in an article entitled "The role of MICE in the development of the tourism industry" concluded that business travel is an important part of tourism, which includes tourists in congresses, conferences, exhibitions, incentive trips, events and corporative trips. Many countries have realized the importance of this part of tourism development and therefore they have an impact on organization, its promotion and realization. Business trips include meetings, incentive trips, congresses, conferences and exhibitions. For this reason, domestic and foreign literature increasingly use the term MICE for this type of travel. This part of the tourist market is a very important part of trade, especially in the case of extending the tourist season, which leads to increase the attractiveness of the tourist destination and the economic effects of the development of this part of the tourist market. Ehsani (2016) in an article entitled "MICE Tourism" concludes that MICE generates justifiable revenue that is higher than regular tourism. It can also be seen that MICE has relatively less impact on the host and the host destination than any tourist activity. In this regard, almost every country in the world is trying to introduce itself as a destination that can provide the best results for business travelers.

\section{Methodology}

The statistical population of research is divided into three parts. The first part included the local residents of Semnan, based on the census, population and housing contained in the Statistics Center of Iran, in 1395, among the population of 125,129 , the number of 390 people were recognized as statistics sample volume according to the Cochrane formula. The second part includes tourists who considered Semnan as a tourist destination from 1398/12/15 to 1399 / 07/15, and the third part includes the academic elites and managers and staff of the tourism sector working in various management levels of the province to an approximate number of 100 people, which the number 80 people has been determined as statistical sample volume using the Cochran formula. The simple random sampling method is used in this research. To collect the present research data, two methods have been used: library method and field methods. In the research of Ajam (1395), the reliability of the questionnaire has been obtained 70\% using Cronbach alpha method. In this research, both SPSS and PLS software are used for data analysis and finally, we will summarize the information using SWOT Meta and SOAR techniques.

The Meta SWOT model is based on an internal-to-external approach and is a kind of resource-based approach. How to identify resources and capabilities capable of creating a sustainable competitive advantage also remains as a challenge. "Barney" offers four main criteria for solving this problem. For a resource to be effective, it must be strategically valuable, rare, inimitable, and irreplaceable. The four proposed criteria can determine the potential resource capacity and capability to create a successful strategy (Qaed Rahmati (2016)).

\section{Findings}

In the Meta-SWOT model, factors related to the organization's environment are identified independently of internal factors. The PESTEL method is used for this identification. This framework is based on political, economic, social, technological, environmental and legal factors. This analysis is effective in identifying the opportunities ahead as well as the probable risks of expanding each collection. Generally, this analysis is used to evaluate the environment on a macro scale as well as to evaluate the present time. Because macro factors have the ability to make fundamental changes in the environment and the collection. However, that firm has not had any impact on these decisions (Kamyabi (2020)). 
Table 1. Objectives set in the MICE tourism development in Semnan by 1404

\begin{tabular}{ll}
\hline Priority & Objectives \\
\hline High priority & Quantitative increase in the number of domestic and foreign tourists in Semnan \\
\hline High priority & Increasing employment in tourism in Semnan \\
\hline High priority & Improving the economic situation \\
\hline High priority & Increasing the level of status and social and cultural relations \\
\hline Medium priority & Identify the ecological and environmental situation \\
\hline High priority & Identifying the potentials of holding local and indigenous festivals in Semnan \\
\hline Medium priority & $\begin{array}{l}\text { Investigation and identification of the province's territorial resources in relation to } \\
\text { tourism development }\end{array}$ \\
\hline Medium priority & Identifying the capabilities and potentials of tourism in Semnan \\
\hline High priority & Increasing the level of economic stability in Semnan \\
\hline High priority & Improving the economic welfare of Semnan residents \\
\hline Medium priority & Increasing the level of economic justice in the city of Semnan \\
\hline High priority & Improving the quality of life of Semnan residents \\
\hline High priority & Increase and improve the level of holding local and indigenous festivals \\
\hline High priority & Strengthen MICE tourism \\
\hline low priority & Increasing the average overnight stay or stay of tourists in Semnan \\
\hline Medium priority & Strengthening the tourism infrastructure of Semnan \\
\hline
\end{tabular}

After determining the objectives, the tourism resources and capabilities of Semnan city will be identified in relation to MICE tourism. These resources and capabilities are the same internal power and potential of Semnan, which should strengthen and identify them to be able to achieve its goals as well as to compete with its competitors and excel. Although these features may not be profitable at the moment, they have potential and valuable power that can be turned into a strength with futuristic planning.

Table 2. Effective resources and capabilities in the tourism development in Semnan

\begin{tabular}{ll}
\hline Resources and capabilities & Weight \\
\hline Existence of local and indigenous festivals & 10 \\
\hline Existence of proper infrastructure & 5 \\
\hline Existence of a network of suitable ways & 7 \\
\hline Private sector investment in MICE tourism & 5 \\
\hline Access to the desert & 6 \\
\hline Provincial level security & 7 \\
\hline climate diversity & 4 \\
\hline Political and economic stability & 8 \\
\hline Locating on the way of passing tourists & 5 \\
\hline Existence of proper hotels and accommodations & 5 \\
\hline Possibility of holding industrial exhibitions & 5 \\
\hline Existence of proper infrastructure for holding sports competitions & 6 \\
\hline Existence of a young and active workforce & 8 \\
\hline Existence of protected areas, national parks and wildlife areas & 4 \\
\hline Existence of urban infrastructure for tourists & \\
\hline
\end{tabular}


Existence of historical monuments and buildings

5

People's participation 2

Determining the competitive dimensions of Semnan's neighbors: In this section, it is determined that Semnan competes with its neighbors over which tourism variables. Therefore, according to many expert cases, these cities are Shahroud, Damghan and Garmsar. Five levels of "very high, high, almost equal, low and very low "were used to do this comparison. These results are shown in Table 3.

Table 3. Comparison of Semnan province with neighboring provinces in terms of factors affecting the MICE tourism development.

\begin{tabular}{|c|c|c|c|c|c|c|c|}
\hline Effective factor & Sari & Qaemshahr & Damghan & Garmsar & Shahroud & Gorgan & Qom \\
\hline $\begin{array}{l}\text { Existence of local and } \\
\text { indigenous festivals }\end{array}$ & low & Equal & high & low & low & Equal & Equal \\
\hline $\begin{array}{l}\text { Existence of proper } \\
\text { infrastructure }\end{array}$ & low & lower & higher & high & lower & Equal & low \\
\hline $\begin{array}{l}\text { Existence of a network } \\
\text { of suitable ways }\end{array}$ & high & Equal & high & high & lower & high & low \\
\hline 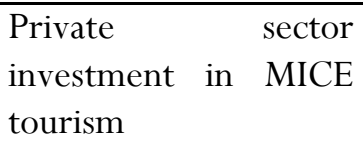 & high & high & lower & lower & Equal & lower & equal \\
\hline Access to the desert & higher & lower & Equal & low & Equal & lower & higher \\
\hline $\begin{array}{ll}\begin{array}{l}\text { Provincial } \\
\text { security }\end{array} & \text { level } \\
\end{array}$ & Equal & high & Equal & Equal & low & Equal & high \\
\hline climate diversity & low & low & Equal & high & Equal & low & high \\
\hline $\begin{array}{l}\text { Political and economic } \\
\text { stability }\end{array}$ & Equal & low & high & high & low & high & low \\
\hline $\begin{array}{l}\text { Locating on the way of } \\
\text { passing tourists }\end{array}$ & high & high & Equal & Equal & Equal & high & Equal \\
\hline $\begin{array}{l}\begin{array}{l}\text { Existence of proper } \\
\text { hotels } \\
\text { accommodations }\end{array} \\
\text { accommon }\end{array}$ & lower & lower & high & higher & lower & higher & low \\
\hline $\begin{array}{l}\text { Possibility of holding } \\
\text { industrial exhibitions }\end{array}$ & high & high & higher & high & low & high & low \\
\hline $\begin{array}{lr}\text { Existence of } & \text { proper } \\
\text { infrastructure } & \text { for } \\
\text { holding } & \text { sports } \\
\text { competitions } & \end{array}$ & high & Equal & high & high & low & high & low \\
\hline $\begin{array}{l}\text { Existence of a young } \\
\text { and active workforce }\end{array}$ & high & low & higher & higher & lower & high & low \\
\hline $\begin{array}{l}\text { Existence of protected } \\
\text { areas, national parks } \\
\text { and wildlife areas }\end{array}$ & high & high & higher & high & high & low & high \\
\hline $\begin{array}{lr}\text { Existence of } & \text { urban } \\
\text { infrastructure } & \text { for } \\
\text { tourists } & \\
& \end{array}$ & low & lower & high & Equal & lower & Equal & higher \\
\hline Existence of historical & Equal & low & Equal & low & lower & Equal & low \\
\hline
\end{tabular}


monuments and

buildings

\begin{tabular}{llllllll}
\hline People's participation & Equal & low & Equal & Equal & lower & low & Equal \\
\hline
\end{tabular}

Based on the factors affecting the development of MICE tourism in neighboring provinces competing with Semnan province, it can be said that Isfahan province with a weight of 4.315 is the largest competitor for the studied province, after Isfahan, Khorasan-Razavi province with a weight of 4.105 and then Qom province with a weight of 3.210, Golestan province with a weight of 2.947, Mazandaran province with a weight of 2.789, North Khorasan province with a weight of 2.473 and South Khorasan with a weight of 2.368 are the main competitors of Semnan province in the MICE tourism industry .

Capability Assessment: At this stage, a resource-based perspective is used to response the challenge of how to identify the sustainable competitive advantage of each the resources and capabilities. Based on this, resources and capabilities are examined and measured in terms of weight, rarity, inimitable and irreplaceability. Table 4 assesses capabilities based on a resource-based perspective.

Table 4. Assess resources and capabilities based on a resource-based perspective

\begin{tabular}{|c|c|c|c|c|}
\hline $\begin{array}{ll}\text { resources } & \text { and } \\
\text { capabilities } & \end{array}$ & weight & rarity & inimitable & irreplaceability \\
\hline $\begin{array}{l}\text { Existence of local and } \\
\text { indigenous festivals }\end{array}$ & 10 & high & medium & medium \\
\hline 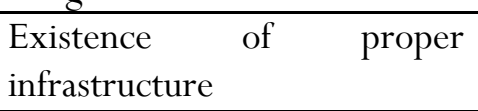 & 5 & medium & medium & medium \\
\hline $\begin{array}{l}\text { Existence of a network of } \\
\text { suitable ways }\end{array}$ & 7 & high & medium & medium \\
\hline $\begin{array}{l}\text { Private sector investment in } \\
\text { MICE tourism }\end{array}$ & 5 & medium & medium & medium \\
\hline Access to the desert & 6 & medium & medium & medium \\
\hline Provincial level security & 8 & high & medium & medium \\
\hline climate diversity & 7 & high & weak & weak \\
\hline $\begin{array}{l}\text { Political and economic } \\
\text { stability }\end{array}$ & 4 & weak & high & high \\
\hline $\begin{array}{l}\text { Locating on the way of } \\
\text { passing tourists }\end{array}$ & 8 & high & weak & weak \\
\hline $\begin{array}{l}\text { Existence of suitable hotels } \\
\text { and accommodations }\end{array}$ & 5 & medium & medium & medium \\
\hline $\begin{array}{l}\text { Possibility of holding } \\
\text { industrial exhibitions }\end{array}$ & 5 & medium & medium & medium \\
\hline $\begin{array}{lll}\text { Existence of } & \text { suitable } \\
\text { infrastructure for } & \text { holding } \\
\text { sports competitions } & \end{array}$ & 5 & medium & medium & medium \\
\hline $\begin{array}{l}\text { Existence of a young and } \\
\text { active workforce }\end{array}$ & 6 & medium & medium & medium \\
\hline $\begin{array}{l}\text { Existence of protected areas, } \\
\text { national parks and wildlife } \\
\text { areas }\end{array}$ & 8 & high & weak & weak \\
\hline Existence $\quad$ of $\quad$ urban & 4 & weak & high & high \\
\hline
\end{tabular}


infrastructure for tourists

\begin{tabular}{lllll}
\hline $\begin{array}{l}\text { Existence of historical } \\
\text { monuments and buildings }\end{array}$ & 5 & medium & medium & medium \\
\hline People's participation & 2 & weak & high & high \\
\hline
\end{tabular}

In this stage, environmental factors affecting outside the control of the organization that affect the space of the study area will be evaluated, which potential analysis will be used for this stage, this analysis is more effective to identify the opportunities ahead as well as the potential risks of expanding each collection. In more general terms, it can be said that PESTEL analysis evaluates the environment in macro dimensions as well as evaluates the present time; and its framework is based on economic, political, social, technological, environmental and legal factors.

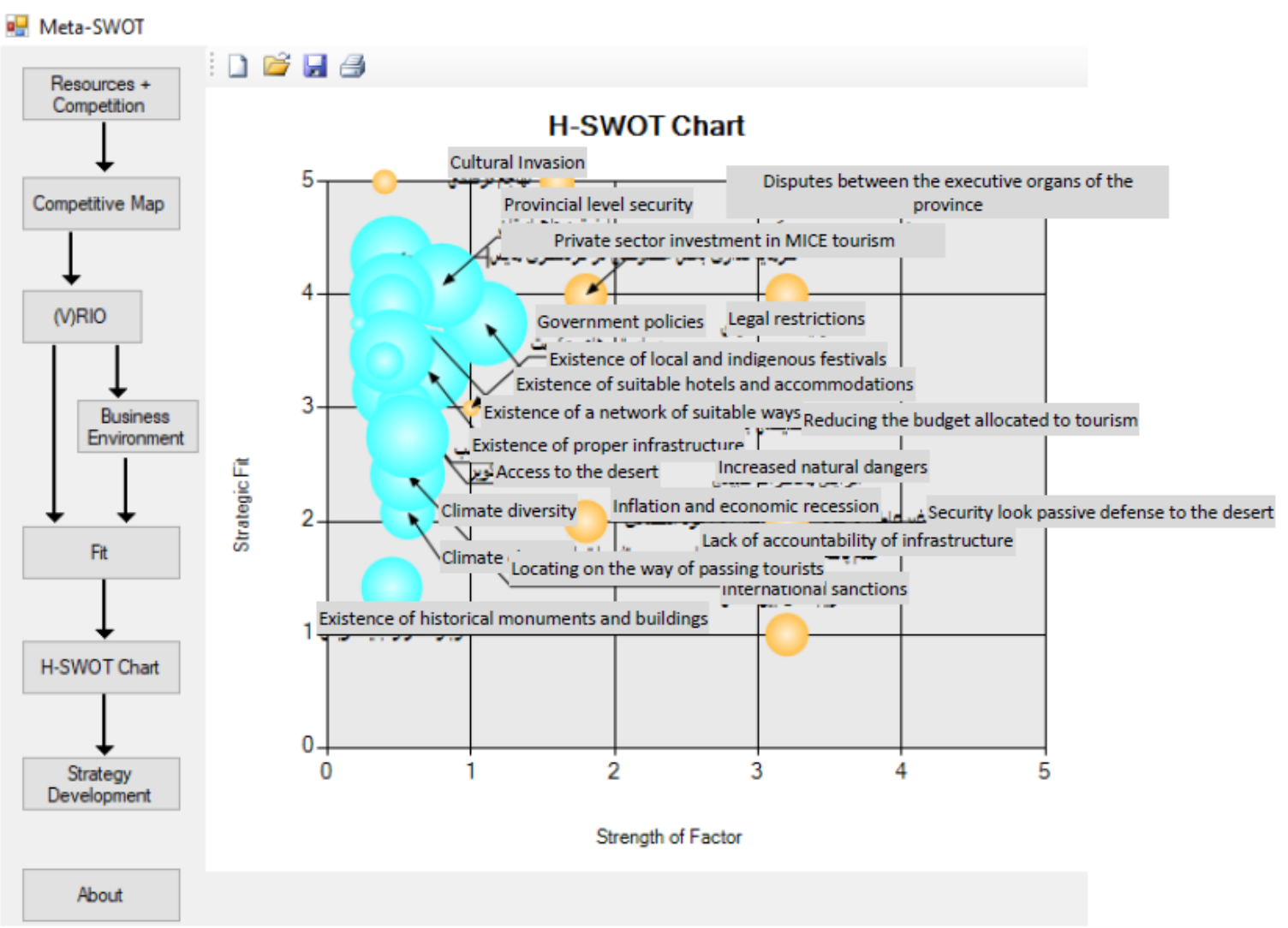

Figure 1. A Strategy for MICE tourism development in Semnan

At this stage, a strategic fit map is drawn with regard to the PESTEL analysis and the comparisons that are made between resources with goals and resources with macro factors, turquoise color in the map indicates resources and capabilities and brown color indicates macro-environmental factors. In the analysis about how to place the bubbles, it should be said that the turquoise bubbles that are inclined to the top and toward the right, are in fact the same resources and internal capabilities of Semnan tourism that have the characteristics such as being valuable, being primitive, inimitable and irreplaceability, which can be used to strengthen regional competitiveness. These resources and capabilities have the most strategic fit with macro factors. In a scientific definition, it can be said that this strategic fit is in fact a planned and expert fit to deal with the negative effects of macro factors and in the discussion of competitiveness with competitors, which has the 
ability for more adaptation and flexible to the conditions caused by the effects of macro factors and competitive effects.

According to the above figure, the economic policies of the government and the lack of knowledge about the province's tourism attractions and the lack of chain link between the province's tourism institutions with each other are considered as the biggest environmental obstacles to the tourism development in Semnan province. Therefore, it needs attention according to the size of the bubble. One of the influential environmental factors that according to the above figure is in the next ranks of impact and necessity, is the reduction of specialized budgets to the tourism sector and inflation and economic recession. Among the factors affecting the development and success of tourism in Semnan province, according to the above figure, passengers and pilgrims traffic of Razavi, advertising, integrated management and manpower have the highest strategic fit for the tourism development in the province, i.e. they are more valuable, rarer, more inimitable and more irreplaceable than other factors. Therefore, special attention should be paid to these factors, but the development of urban infrastructure and the development of communication roads, as well as the diversification of communication roads should be a priority in executive measures for the development and success of MICE tourism in Semnan province.

\section{Conclusion}

According to the results from different sections perspectives of the statistical community, important and effective factors from their perspectives can be introduced as follows:

Table 5. Priorities from the perspective of all three communities

\begin{tabular}{|c|c|c|}
\hline $\begin{array}{l}\text { Prioritization of factors from } \\
\text { the perspective of the elites }\end{array}$ & $\begin{array}{l}\text { Prioritization of factors from } \\
\text { the perspective of residents }\end{array}$ & $\begin{array}{l}\text { Prioritization of factors from } \\
\text { the perspective of tourists }\end{array}$ \\
\hline Government policies & Government policies & $\begin{array}{l}\text { Lack of accountability of } \\
\text { infrastructure }\end{array}$ \\
\hline Increased natural dangers & Inflation and economic recession & Increased natural dangers \\
\hline International sanctions & $\begin{array}{l}\text { Lack of accountability of } \\
\text { infrastructure }\end{array}$ & Climate changes \\
\hline $\begin{array}{l}\text { Lack of accountability of } \\
\text { infrastructure }\end{array}$ & International sanctions & $\begin{array}{l}\text { Security look and passive defense } \\
\text { to the desert }\end{array}$ \\
\hline $\begin{array}{l}\text { Reducing the budget allocated to } \\
\text { tourism }\end{array}$ & $\begin{array}{l}\text { Disputes between the executive } \\
\text { organs of the province }\end{array}$ & $\begin{array}{l}\text { Disputes between the executive } \\
\text { organs of the province }\end{array}$ \\
\hline Legal restrictions & Cultural Invasion & $\begin{array}{l}\text { Reducing the budget allocated to } \\
\text { tourism }\end{array}$ \\
\hline Inflation and economic recession & $\begin{array}{l}\text { Reducing the budget allocated to } \\
\text { tourism }\end{array}$ & $\begin{array}{l}\text { Mismatch between local culture } \\
\text { and tourist culture }\end{array}$ \\
\hline Climate changes & $\begin{array}{l}\text { Security look and passive defense } \\
\text { to the desert }\end{array}$ & Inflation and economic recession \\
\hline $\begin{array}{l}\text { Disputes between the executive } \\
\text { organs of the province }\end{array}$ & Legal restrictions & International sanctions \\
\hline Cultural Invasion & Increased natural dangers & Legal restrictions \\
\hline $\begin{array}{l}\text { Security look and passive defense } \\
\text { to the desert }\end{array}$ & Climate changes & Government policies \\
\hline
\end{tabular}

Positivist perspective (AI) in a strategic planning identifies and creates current strengths and those profitable opportunities instead of focusing on problems, weaknesses and threats (Khavarian et.al, 1392: 133). In the traditional process of strategic planning - SWOT strategy as an example, includes strengths and opportunities and weaknesses and threats (2001, Karppi, Kokkonen, and Lahteenpdki), if we want to divide it 
into two $50 / 50$ parts in terms of intellectual order, we have to assign $50 \%$ of our time on the positive points and 50\% on the negative points. Man instinctively tends to reinforce and focus on the negative points. In the positivist perspective, we will develop the strengths and opportunities there to enable covering weaknesses and threats (Cooperrider and Whitney 2009, Stavros and Saint 2009). The benefits of a positivist perspective in strategic planning include the following cases:

- Focus on the positive points to cover the negative points.

- Create capabilities beyond the current territory.

- Establish communication between participants

- Earn input from all levels.

- Planning changes in to a process that combines the values, visions, and missions and turning them into strategic goals, positive and purposeful reviews in goals.

- Creating perspectives and values as a partnership for the future.

In recent years, scientists and experts have succeed to improve and increase the efficiency of this model by combining the SWOT model with the intellectual principles and system of the positivist perspective(AI), and a new SOAR model was created. Thus, the SWOT model reflects external competitive factors and the positivist perspective (AI) reflects the motivation and internal environmental system. Of course, weaknesses and threats cannot be clearly identified, but the effective and practical structure of the positivist perspective (AI) will cover these issues (Stavros, Cooperrider, and Kelley, 2003).

Analyzing strengths, opportunities, wants and aspirations, and expected results is a strategic tool. This tool integrates data related to the current position of the organization with the ideas and dreams that people have for the future in order to achieve an energetic vision (Firoozi, Zadoli Khajeh, 1396: 32).

SOAR relies on the experiences of all employees in the organization at different application levels and departments, while SWOT is usually a managerial approach. The second difference is that SOAR is based on valuable research, so it focuses on cases the organization can do well and tries to turn weaknesses and threats into opportunities.

SOAR strategy begins with a strategic research. In this research, the biggest strengths and opportunities in the society will be discovered through the participants and shareholders (those who have share). Participants in this process are then invited to choose the ideals and aspirations for themselves that they prefer to achieve in the future. Finally, the desired measurable results will be selected through incentive and review programs. The SOAR strategy consists of four key parts that include identifying strengths, opportunities, ideals, and results (Rezaei, Khavarian, Ghafourzadeh (2015)).

Of course, threats and problems will not be ignored, they will be reshaped and examined through a microscope of possibilities. Identifying collections with positive function and core introduce us the valuable and useful things, networks, abilities, and creative thoughts, and in general, everything that drives us to progress. In short, SOAR positive-finder strategy opens a new horizon beyond traditional strategic planning perspectives. This new horizon is associated with highlighting the strengths, opportunities and aspirations of a collections and involving different groups of people who have a share in the community.

In the first step, the main goals of the research should be identified and since these goals do not have the same weight, experts were asked to prioritize them at three levels (high, medium and low) according to their importance of each of the identified goals ).

Analyzing strengths, opportunities, wants and aspirations, and expected results is a strategic tool. This tool integrates data related to the current position of the organization with the ideas and dreams that people have for the future in order to achieve an energetic vision.

SOAR relies on the experiences of all employees in the organization at different application levels and departments, while SWOT is usually a managerial approach. The second difference is that SOAR is based on valuable research, so it focuses on what the organization can do well and tries to turn weaknesses and threats into opportunities. 


\section{Reference}

Bazrafshan M. (2017). Creative Tourism, Tehran, Mahkameh Publications.

Ehsani A. (2016). Ecotourism is a way to sustainable tourism, Tehran, Publishing Court, Third Edition.

Firoozi M, Zadkhajeh Vali Sh. (2017). SOAR Strategic Model A Step Towards Strategic Planning for Urban Tourism Development (Case Study: Tabriz Metropolis), Regional Planning Quarterly.

Kamyabi S. (2020). Strategic Tourism Planning of Semnan Province Using Meta SWOT Technique, Quarterly Journal of Development Strategy, Year 16, Number 2 (consecutive 62), Summer, pp. 165 141.

Karppi I, Kokkonen M, Lähteenmäki-Smith K. (2001): SWOT-analysis as a basis for regional strategies. Nordregio WP, 4, 80.

Kazemi M. (2006). Tourism Management, Tehran, Samat Publications.

Mahmoudi M, Moghaddami M. (2012). New Management of World Tourism, Tehran: Mahkameh Publications, Second Edition.

Nasirian J. (2017). Etiquette, Behavioral Patterns and Professional Ethics in the Tourism Industry, Tehran, Mahkameh Publications, Fourth Edition.

Pirmohammadzadeh A. (2018). MICE Tourism, Mahkameh Publications.

Qaed Rahmati S. (2016). The Role of Meta SWOT Technique in Strategic Tourism Planning in Yazd, Journal of Spatial Planning and Planning.

Ranjbarian B, Zahedi M. (2006). Knowledge of Tourism, Chaharbagh Publications

Rezaei M, Khavarian A, Ghafourzadeh M. (2015). Industry Development in Yazd Province Using SOAR Strategic Framework and ANSOFF Matrix, Journal of Spatial Planning and Planning.

Shiran S. (2013). Geography and Tourism Industry, Payame Noor University Press. Regional Planning Quarterly.

Shokohi M, Shakermi N, Mansourzadeh A. (2018). Strategic planning of Kurdistan tourism based on regional competitiveness identity using Meta-SWOT technique, Quarterly Journal of Urban Studies, No. 26, Spring, pp. 17-30.

Smith M, McLeod N, Robertson M H. (2012). Key Concepts in Tourism Studies, translated by Jafar Bapiri, Tehran: Mahkameh Publications.

Zandmoghaddam M, Pir Mohammadzadeh A. (2018). The Role of Strategic Event Planning in the Development of the Tourism Industry, The First International Conference on Interdisciplinary Studies in Management and Engineering, University of Tehran, March. 